\title{
Buyer-driven Greening? Cargo-Owners and Environmental Upgrading in Maritime Shipping
}

Taudal Poulsen, René; Ponte, Stefano; Lister, Jane

Document Version

Accepted author manuscript

Published in:

Geoforum

DOI:

10.1016/j.geoforum.2015.11.018

Publication date:

2016

License

CC BY-NC-ND

Citation for published version (APA):

Taudal Poulsen, R., Ponte, S., \& Lister, J. (2016). Buyer-driven Greening? Cargo-Owners and Environmental Upgrading in Maritime Shipping. Geoforum, 68(jan), 57-68. https://doi.org/10.1016/j.geoforum.2015.11.018

Link to publication in CBS Research Portal

\section{General rights}

Copyright and moral rights for the publications made accessible in the public portal are retained by the authors and/or other copyright owners and it is a condition of accessing publications that users recognise and abide by the legal requirements associated with these rights.

Take down policy

If you believe that this document breaches copyright please contact us (research.lib@cbs.dk) providing details, and we will remove access to the work immediately and investigate your claim. 


\section{Buyer-driven Greening?: Cargo-Owners and Environmental Upgrading in Maritime Shipping}

\section{René Taudal Poulsen, Stefano Ponte, and Jane Lister}

Journal article (Post print version)

CITE: Buyer-driven Greening?: Cargo-Owners and Environmental Upgrading in Maritime Shipping. / Taudal Poulsen, René; Ponte, Stefano; Lister, Jane. In:

Geoforum, Vol. 68, No. jan, 2016, p. 57-68.

DOI: 10.1016/j.geoforum.2015.11.018

Uploaded to Research@CBS: May २०17

(C) 2016. This manuscript version is made available under the CC-BY-NC-ND 4.0 license http://creativecommons.org/licenses/by-nc-nd/4.0/ 


\title{
Buyer-driven greening? Cargo-owners and environmental upgrading in maritime shipping
}

\begin{abstract}
In this article, we examine the relations between global value chain governance and environmental upgrading in maritime shipping. Drawing from interviews with global shipping companies and major buyers of shipping services (cargo-owners), we reveal the key issues and challenges faced in improving the environmental performance of maritime transportation. Contributing to the GVC literature, we compare and analyse the influence of three main external drivers on environmental upgrading in the tanker, bulk and container shipping segments: regulation, cooperation and buyer demands. Our findings suggest that environmental upgrading is more likely to occur when global value chains are characterised by unipolar governance and where the lead firms are consumer-facing companies with reputational risks. Furthermore, environmental upgrading in shipping is not likely to materialise without clear and enforceable global regulation and stronger alignment between regulation and voluntary sustainability initiatives.
\end{abstract}

Keywords: environmental upgrading; global value chains; sustainability; corporate environmental responsibility; maritime shipping

\section{Introduction}

In economic geography and international political economy, the concept of value chain refers to 'the full range of activities that firms and workers perform to bring a specific product from its conception to its end use and beyond' (Gereffi \& Fernandez-Stark, 2011:4). This includes activities such as design, production, marketing, transport, retail, and disposal or recycling. The concept of 'global value chain' (GVC) refers to the configuration of these coordinated activities that are 'divided among firms and that have a global geographical scale' (Gibbon and Ponte, 2005:77). At the nexus of GVCs lie the contractual linkages of formally independent firms, whether as result of the outsourcing and offshoring of previously integrated functions carried out by multi-national corporations, or through the contractual subordination of suppliers previously linked through open market transactions (Gereffi et al. 1994; Cattaneo et al. 2010).

The emergence and expansion of GVCs in the past three decades have increased the salience of logistics (Memedović et al., 2008; Coe and Hess, 2013a; Coe, 2014) and transport (including maritime shipping) for understanding the dynamics of the global economy. The de-integration of production and its functional integration that characterized this period has led to increasing trade in intermediate products, lean and agile procurement and inventory systems, and heightened flexibility of provisions systems overall (Scherer and Palazzo 2010; Dicken, 2011; Sturgeon and Memedović, 2011; Gereffi, 2014). In this context, maritime shipping has remained essential in the operation of the contemporary global economy - also thanks to containerization and vast economies of scale (Hummels, 2007; Levinson, 2006; Kaukiainen, 2014).

At the same time, societal and political pressure to improve the environmental footprint of production and distribution of goods has raised new challenges for producers, processors and retailers of goods and services, especially those that are branded and offered directly to 
consumers (Dauvergne and Lister, 2013). This has led to innovations aiming at decreasing the environmental footprints, and especially levels of carbon dioxide $\left(\mathrm{CO}_{2}\right)$ emissions, of production and transport - processes that the GVC literature frames as 'environmental upgrading' (Jeppesen and Hansen, 2004; Ivarsson and Alvstam, 2010; De Marchi et al., 2012; 2013; Goger, 2013).

While there is now a rich literature on the dynamics and challenges of governance and upgrading in GVCs in an increasingly complex global economy (Gereffi et al. 1994; Gibbon and Ponte, 2005; Bair, 2009; Cattaneo et al., 2013, among many others), surprisingly little work of this kind has focused on transport, and on maritime shipping in particular. Much of the literature on shipping governance has either appeared in specialist shipping journals or in the business studies tradition of supply chain management, which are mainly focused on sectoral policy and firm-level strategy. There has been little to no recent research analyzing the external interactions between shipping as an industry itself and the various GVCs that use its services. To our knowledge, this article is the first to examine environmental upgrading in maritime shipping in relation to the operation of GVCs.

Public discussions about environmental problems caused by international shipping can be traced back several decades (Mukherjee and Brownrigg, 2013). Since the advent of supertankers in the 1960s, the issue of oil spills from tanker shipping has received considerable attention by the public. While concern about spills has a long history (Huijer, 2005; Burgherr, 2007) and remains an issue (particularly after the Exxon Valdez spill in 1989), in recent years other environmental concerns have also received significant public attention. These concerns reflect the contemporary environmental agenda, but also the particular nature of the global and highly mobile shipping industry. From 2007 to 2012, international shipping accounted for approximately 2.8 per cent of global $\mathrm{CO}_{2}$ emissions (IMO, 2014b).

The lack of research on the interactions between GVC operators (what we call 'cargoowners') and shipping companies is particularly surprising. On the one hand, shipping provides the mode of transport with the lowest $\mathrm{CO}_{2}$ emissions per ton-mile (Buhaug et al., 2009) - accordingly, pressures to decrease $\mathrm{CO}_{2}$ emissions among cargo-owners are leading industries to move part of their transport needs from air to ship (Mathers, 2012). On the other hand, the shipping industry is perceived as one of the laggards in processes of environmental upgrading (Anderson and Bows, 2012; Authors, 2015). Given this tension and uncertain environmental outcome, it is therefore, important to understand the evolving dynamics of this sector with respect to the shifting relations between cargo-owners (the 'buyers' of shipping services) and shipping companies within the multi-level and uncertain global shipping regulatory context.

In this article, we seek to start filling this knowledge gap by examining the role played by cargo-owners in driving environmental upgrading in shipping, and the challenges of this process. The purpose here is not to provide a full GVC analysis of the shipping industry, nor of the intersecting value chains where shipping services are provided, but rather to shed more light on the value chain drivers of environmental upgrading. This approach has three implications: (1) we focus on drivers that are external to the firm (i.e. demands posed by buyers of shipping services and/or formulated in cooperative efforts, such as in multistakeholder initiatives) rather than on drivers that are internal to the firm (i.e. technological innovation, operational improvements or cost-optimization measures put in place by shipping companies themselves); the internal factors are well covered in the specialist shipping literature; (2) although we discuss drivers of environmental upgrading 
arising from regulation and cooperative efforts (which we cover in more detail elsewhere; see Authors, 2015), we focus mostly on business-to-business factors; and (3) we explicitly link GVC governance dynamics (i.e. the level of influence of the external driver, and the polarity of governance) to environmental upgrading paths.

The paper is organized is six sections. In section 2 , we explain our methods. In section 3 , we briefly summarize the main issues arising from the GVC literature in relation to environmental upgrading and the links between GVC governance and upgrading. In section 4, we analyse the main external drivers of environmental upgrading in the shipping industry: first, we provide an explanation of the pressures within the regulatory landscape; second, we examine the role of cooperative 'green shipping' efforts developed through industry and multi-stakeholder initiatives (MSIs); and third, we explain and compare the influence of buyer demands in the three main shipping segments (dry-bulk, tanker and container). In section 5, we lay out the key issues of 'buyer-driven' environmental upgrading in the shipping industry. In the conclusion, we reflect upon what our analysis means for the future of environmental upgrading in GVCs, together with reflection on future research needs in this field.

\section{Methods}

The analysis of environmental upgrading is relatively recent within the field of GVC research, and is empirically under-investigated in maritime shipping. Furthermore, previous experience of some of the authors in researching the shipping industry suggested that the issue of environmental regulation of the sector is complex, and commercially and politically very sensitive. Therefore, we adopted a qualitative research approach based on semistructured interviews, and offered full confidentiality, in order to gain a richer, more nuanced understanding of whether consumer goods cargo-owners are influencing the environmental practices of shipping carriers. Specifically, our methodology included primary data collection through expert interviews with executives and middle-managers at a stratified sample (within the global industry) of high performing shipping companies and consumer goods cargo-owning companies. We triangulated the interviews with an in-depth secondary literature review and analysis of CSR and/or sustainability reports (where available) of shipping companies and cargo-owners, and current material on transnational environmental rating schemes in maritime shipping. Our interviews focused on the perceptions and experiences of the company representatives regarding the incentive structure and management of environmental issues in shipping. Our three main research questions were:

(1) What are the environmental demands that cargo-owners are placing on shipping companies when contracting their services, and whether and why is this occurring? (2) What are the views of main stakeholders on the benefits and challenges of the voluntary environmental rating schemes in international shipping? and (3)What are their perceptions on the overall drivers of change towards improved environmental protection in shipping?

Our research sample includes a total of 45 interviews (40 with shipping companies, 5 with cargo owners) in 31 companies (26 shipping companies and 4 cargo owners) over a period of two years (mid-2012 to mid-2014). ${ }^{1}$ On the supplier side (providers of shipping services), we interviewed 10 persons in 9 dry bulk companies; 22 persons in 12 tanker companies; and 8 persons in 5 container companies. The rationale for this sampling approach was that these are the three main segments in global shipping, and where most cargo is carried in terms of volume and value (Asariotis et al., 2013). Given the range of business considerations in environmental management, we selected executives and middle-managers from both 
commercial and technical positions, including: top management, sustainability departments and technical departments with environmental expertise, chartering departments (which negotiate freights with cargo-owners) and operational departments (which operate the ships). Our overall sample includes a majority of Danish shipping companies, as they have generally more transparent environmental policies than the global population of shipping companies, and it is reasonable to assume that environmental upgrading that goes beyond regulatory compliance is most likely to initiate among such companies. As our focus is on frontline movers, we also interviewed the two largest Canadian shipping companies and a German company (in the tanker and container segments).

On the buyer side (buyers of shipping services, i.e. cargo-owners), first we conducted an indepth desk review of the literature on sustainability efforts in transportation by branded cargo-owners, including a comparative analysis of sustainability commitments and efforts in maritime shipping as reported in the annual CSR/sustainability reports of the largest container import customers to the US (JOC, 2012). Second, we tested the findings of our desk review analysis by conducting semi-structured and confidential interviews. This included five interviews with four Nordic cargo-owner companies, which manufacture various types of branded consumer goods. We selected these companies on the criteria that they have clearly formulated sustainability strategies with quantified environmental targets and specific deadlines. The targets include addressing their supply chain environmental footprint, including transport. Within their respective businesses, they are currently among those with the clearest and most ambitious environmental targets and it is reasonable to expect that such companies will be first movers in terms of posing new environmental demands to shipping companies. The cargo-owners we selected to interview buy raw materials and semi-manufactured products globally, have their own production sites in several continents, and sell their products globally. They rely on maritime shipping for both inbound intermediate materials and for outbound finished goods. They consequently have a considerable need for frequent and global transportation services, mainly for containerized cargo. Our interviews specifically targeted the transportation procurement managers, as they make the decisions on which shipping companies to contract.

Except for five interviews, our interviews were tape recorded and transcribed verbatim, and subsequently coded electronically with NVivo software. We coded according to the three main aspects from the interview guides, and thus identified prevailing attitudes and experiences among interviewees in each shipping segment. We also used the transcribed interviews and codes to identify disagreements between interviewees. Comparisons were particularly relevant for understanding the differences between segments in terms of drivers for environmental upgrading, as we detail in the next sections.

It is critical to note here that we performed our interviews between 2012 and 2014, when there was excess supply of global shipping capacity, and freight rates in all shipping segments were very low (Asariotis et al., 2013). In an industry that is characteristically highly cyclical, the conditions at this time constituted a 'buyer's market' whereby cargoowners had a relative upper hand in freight negotiations. This provided an opportune window for our research: if cargo-owners were to exert environmental demands, we would be more likely observe it at this time.

\section{Global value chains and environmental upgrading}


Increased consumer awareness of the environmental impact of production and transportation of goods, numerous campaigns and direct action by NGOs and other civil society groups, and emerging national and international regulation are forcing corporate actors along value chains to assess and address the environmental impact of activities linked to their products, also beyond those carried in-house. The fact that production is increasingly fragmented geographically and organizationally poses specific challenges to value chain actors seeking to reduce their environmental footprint. This is especially the case when it comes to influencing the activities of their suppliers, including those providing maritime shipping services. The many scandals that have touched branded companies in particular have led them to devise environmental responsibility strategies for their own operations and for those of their suppliers to avoid reputational risk (Nadvi, 2008; Vurro et al., 2010), and to increasingly participate in multi-stakeholder initiatives setting norms and standards for sustainability issues in global value chains (for a recent review of this emerging literature, see Wahl and Bull, 2014).

The analysis of the greening of industries from a GVC perspective is still in its infancy, although a few contributions have attempted to provide a conceptual framework to include sustainability concerns (Bolwig et al., 2010). These efforts are generally framed in the context of GVC discussions on governance and upgrading.

The concept of governance in GVCs is based on the assumption that, while both disintegration of production and its re-integration through inter-firm trade have recognizable dynamics, they do not occur spontaneously, automatically, or even systematically (Gibbon et al., 2008). Instead, these processes are 'driven' by the strategies and decisions of specific actors in value chains. In this approach, governance shapes a specific functional division of labour with a specific geography. Because some activities have higher entry barriers and are more profitable than others, this division of labour influences the allocation of resources and distribution of gains among chain actors. A group of 'lead firms' play a critical role in governing by defining the terms of supply chain membership, incorporating or excluding other actors, and allocating where, when, and by whom value is added (Gereffi, 1994; Gibbon and Ponte 2005; Ponte and Sturgeon 2014).

Much of the existing GVC literature has focused on 'unipolar' value chains - be they buyer-driven, producer-driven (Gereffi, 1994), or international trader-driven (Gibbon, 2001) - where 'lead firms' play a dominant role in shaping the chain. Some scholars have explored the dynamics of governance in GVCs characterized as 'bipolar' or 'twin-driven', where two sets of actors in different functional positions both drive the chain, albeit in different ways (Fold 2002; Islam 2009). Ponte and Sturgeon (2014) also suggest paying attention to 'multipolar' chains, which are different from 'markets' as they are strongly shaped by the explicit strategic actions of powerful actors (both inside and outside the chain), even if they exhibit multiple foci of power and various kinds of linkages. They also argue that levels of 'drivenness' are likely to be higher in unipolar chains, where power is concentrated, than in multi-polar chains, where power is more dispersed. These distinctions are important for the case study of shipping, where two sets of very powerful actors (shipping companies and cargo-owners) suggest the presence of 'bipolar' governance and thus only partial leverage from cargo owners in transmitting environmental upgrading pressures on to shipping companies (see section 4).

In GVC analysis, the term upgrading has been used to highlight paths for value chain actors to 'move up the value chain' for economic gains. The upgrading process is examined 
through the lenses of how knowledge and information flow within value chains from lead firms to their suppliers (or buyers) (Gereffi, 1999). In the GVC literature, 'economic' upgrading is traditionally analysed through four categories (Humphrey and Schmitz, 2002; Schmitz, 2006): (1) product upgrading: moving into more sophisticated products with increased unit value; (2) process upgrading: achieving a more efficient transformation of inputs into outputs through the reorganization of productive activities; (3) functional upgrading: acquiring new functions (or abandoning old ones) that increase the skill content of activities; and (4) inter-chain upgrading: applying competences acquired in one function of a chain and using them in a different sector/chain.

GVC scholars initially focused on a 'high road' to upgrading, eventually leading to performing functions in a value chain that have more skill and knowledge content (functional upgrading) (Gereffi, 1999). But the more recent literature has highlighted a more complex set of upgrading (and downgrading) trajectories (Gibbon, 2001; Giuliani et al., 2005; Tokatli, 2007; Gibbon and Ponte, 2005; Ponte and Ewert, 2009; Mitchell and Coles, 2011; Cattaneo et al., 2013; Ponte et al., 2014), while other scholars are re-framing the upgrading discussion in relation to the charting of 'value capture trajectories' (Yeung and Coe, 2014; Coe and Yeung, 2015). Recent efforts have also attempted to go beyond the discussion of 'economic' upgrading to also examine 'social' upgrading trajectories, and the interactions between the two (Barrientos, 2013a; Barrientos et al., 2010, 2011; Coe and Hess 2013a; 2013b; Rossi 2013; Gereffi and Lee, 2014).

This research agenda is now expanding to the environmental aspects of upgrading in GVCs (Jeppesen and Hansen, 2004; Ivarsson and Alvstam, 2010; De Marchi et al., 2013; Goger, 2013), showing that environmental upgrading can contribute to further consolidation in highly-driven GVCs, as buyers can use it to extract concessions from suppliers (Tokatli et al., 2008; Goger, 2013; Barrientos, 2013b). Recent work has also attempted to build links between 'green business strategies' and GVC upgrading trajectories (De Marchi et al. 2012). This article draws on this literature, examining the possible environmental upgrading trajectories in the shipping industry that may result from pressure by cargo-owners (buyers of shipping services) and the unclear conditions, incentives and implications it may have for shipping companies (suppliers of shipping services).

We find that a promising approach emerging in the existing literature is one that links GVC governance and upgrading through the examination of drivers, and particularly the distinction between 'standard-driven' and 'mentoring-driven greening processes (De Marchi et al. 2013). In standard-driven greening, lead 'buyers' in unipolar and consequently, highly-driven chains identify the main environmental impacts to be reduced, decide how to deal with them, and embed such information into standards that suppliers have to comply with (Jeppesen and Hansen, 2004; De Marchi et al. 2013). These standards may affect both the supplier selection process and the relation between lead firms and existing suppliers. When standards can be met through established third party certifications that suppliers have the capacity to comply with, buyers can stimulate environmental upgrading in a relatively hands-off manner. However, when certifications are not available and/or supplier capacity to meet these standards is lacking, they are enforced through closer and stronger monitoring and control efforts, which often involve knowledge transfer in a relatively top-down manner and the provision of other supporting tools (Jeppesen and Hansen, 2004; Ivarsson and Alvstam, 2010; De Marchi et al. 2013). 
In mentoring-driven greening, personal interactions by the lead buyer with suppliers are of key importance. Governance in these value chains is often bipolar or multipolar, and levels of driving are lower than in unipolar value chains (Ponte and Sturgeon, 2014). Transactions are complex and handled through trust, reputation and face-to-face interactions. Actors tend to be mutually dependent on knowledge and skills: the lead firm usually exerts leadership on environmental knowledge, but suppliers have a lead on technical knowledge (De Marchi et al. 2013; see also Lee and Kim, 2011). Environmental problems and their solutions are considered on a case-to-case basis and do not necessarily need to fit easy-to-measure metrics. The main tools used by the lead firm are design and product specifications, which enable suppliers to improve their environmental performance even if they have a low environmental awareness to begin with (De Marchi et al. 2013).

In this article, we further contribute to this emerging approach by examining the drivers of environmental upgrading in maritime shipping. The role of services (such as shipping and logistics) in GVCs, as highlighted by Coe (2014; see also Coe and Hess, 2013a), has been under-researched, and work on the interaction between service providers (e.g., shipping companies) and lead firms (e.g., cargo owners) in relation to environmental issues and the functioning of GVCs is particularly lacking.

To clarify the main concept, we see environmental upgrading as the process of improving the environmental impact of value chain operations (including production, processing, distribution, consumption and disposal or recycling). Sometimes, these processes lead to net cost reductions for operators due to, for example, increased efficiency or reduced energy consumption. Other times, they lead to net value addition, for example through the creation, valorization and/or certification of new 'environmental qualities' embedded in products that sell at a premium. But in other instances, they impose net costs in the short term, which are not necessarily recouped. If they are, this can happen through higher prices charged to buyers, trimming margins, achieving lower costs in the longer term, and/or achieving economies of scale if the matching of environmental demands entails higher volume of demand. Environmental upgrading can be limited to the improvement of processes, the use of new materials/technologies and/or the integration of systems - but can also lead to upgraded products that embed environmental value through branding and positioning strategies, or through certification to obtain an ecolabel.

The specialized literature on shipping has already highlighted the main internal drivers of environmental upgrading within shipping companies: fuel savings and energy prices. Following a considerable rise in fuel costs in the early 2000s, energy efficiency measures have received increasing attention from industry as well as researchers. $\mathrm{CO}_{2}$ emissions are linearly related to fuel consumption, and up to a certain level, energy efficiency enhancement represents a win-win for business and the environment. Since the issue of energy efficiency in shipping is covered elsewhere (see e.g. Buhaug et al., 2009, Faber et al., 2011, Eide et al., 2011, Acciaro et al. 2013, Jafarzadeh and Utne, 2014; Johnson and Anderson, 2014; Poulsen and Johnson, 2015) we do not address it further here. Rather, we focus on the possible external drivers of environmental upgrading (see section 4): regulation (4.1), various forms of cooperation - business-to-business as well as of multi-stakeholder nature (4.2), but especially the buyer-driven demands that are emerging (4.3) - specifically, the requirements posed by cargo-owners to shipping companies when conditions for maritime transportation are negotiated between them in the context of a fragmented and uncertain regulatory framework. 


\section{External drivers of environmental upgrading in maritime shipping: regulation, cooperation and buyer demands}

\subsection{Regulation}

The regulatory landscape for driving environmental improvements in shipping is lagging, fragmented and uncertain. Although new regulations are proposed and emerging, the drive in changing business practices is currently weak. This holds true across the major global environmental issue areas, including air emissions and invasive species.

Standards for maritime safety and environmental protection are formulated and adopted by United Nations' International Maritime Organization (IMO), and subsequently implemented by national governments (so-called flag-states) in national legislation. The IMO's International Convention for the Prevention of Pollution from Ships (MARPOL) represents the main body of the international regulatory framework for marine pollution from international shipping (see Table 1). In 2013, the IMO introduced two new measures to stimulate environmental upgrading in international shipping through the reduction of $\mathrm{CO}_{2}$ emissions: The Energy Efficiency Design Index (EEDI) and the Ship Energy Efficiency Management Plan (SEEMP). The EEDI applies to all new ships and defines vessel design conditions with the aim of reducing $\mathrm{CO}_{2}$ emissions relative to the transport work performed. The SEEMP is a mandatory plan for all ships, aimed at reducing fuel consumption in the daily ship operation. Studies have shown that EEDI and SEEMP will only slow down growth in $\mathrm{CO}_{2}$ emissions, but will not achieve actual reductions due to an expected growth in demand for maritime shipping (Bazari and Longva, 2011). From 2018, the European Union will implement a mandatory scheme for monitoring, reporting and verification of $\mathrm{CO}_{2}$ emissions from shipping (MRV). This is seen as a first step towards introduction of a market-based measure to reduce $\mathrm{CO}_{2}$ emissions from shipping. So far, regional and international carbon management efforts have been weak and uncoordinated.

Table 1. Main external drivers of possible environmental upgrading in container shipping.

\begin{tabular}{|c|c|c|c|}
\hline Issues & Regulatory tools & $\begin{array}{c}\text { Industry initiatives } \\
\text { and MSIs }\end{array}$ & Buyer-driven demands \\
\hline \multirow{3}{*}{$\begin{array}{l}\mathrm{CO} 2 \text { emission } \\
\text { reduction \& } \\
\text { improved fuel } \\
\text { efficiency }\end{array}$} & $\begin{array}{l}\text { IMO MARPOL } \\
\text { Convention }\end{array}$ & $\begin{array}{l}\text { Clean Cargo } \\
\text { Working Group } \\
\quad(\text { CCWG })\end{array}$ & $\begin{array}{l}\text { A handful of cargo owners } \\
\text { are including environmental } \\
\text { performance on fuel } \\
\text { efficiency and CO2 } \\
\text { emissions in their pricing } \\
\text { models when buying } \\
\text { shipping services }\end{array}$ \\
\hline & $\begin{array}{l}\text { IMO's Energy } \\
\text { Efficiency Design } \\
\text { Index (EEDI) }\end{array}$ & $\begin{array}{c}\text { Sustainable } \\
\text { Shipping Initiative } \\
\text { (SSI) }\end{array}$ & $\begin{array}{l}\text { A small number of cargo } \\
\text { owners use these indicators } \\
\text { for procurement decisions } \\
\text { (volume allocation) }\end{array}$ \\
\hline & $\begin{array}{l}\text { IMO's Ship Energy } \\
\text { Efficiency } \\
\text { Management Plan } \\
\text { (SEEMP) }\end{array}$ & $\begin{array}{l}\text { A variety of 'green } \\
\text { shipping' rating } \\
\text { schemes }\end{array}$ & $\begin{array}{l}\text { A larger, but still small in } \\
\text { absolute terms, number of } \\
\text { cargo owners are starting to } \\
\text { collect data on suppliers' fuel }\end{array}$ \\
\hline
\end{tabular}




\begin{tabular}{|c|c|c|c|}
\hline & $\begin{array}{l}\text { EU mandatory scheme } \\
\text { for monitoring, } \\
\text { reporting and } \\
\text { verification of } \mathrm{CO} 2 \\
\text { emissions from } \\
\text { shipping (MRV) } \\
\text { (under discussion) }\end{array}$ & $\begin{array}{l}\text { Carbon Disclosure } \\
\text { Project (CDP) }\end{array}$ & $\begin{array}{c}\text { efficiency and } \mathrm{CO} 2 \text { emission } \\
\text { performance }\end{array}$ \\
\hline \multirow{3}{*}{$\begin{array}{l}\text { SOx and NOx } \\
\text { emission } \\
\text { reduction }\end{array}$} & $\begin{array}{l}\text { IMO MARPOL } \\
\text { Convention: Regional } \\
\text { regulation fuel- } \\
\text { sulphur content } \\
\text { (SECA) for the Baltic } \\
\text { and North Sea and } \\
\text { North American } \\
\text { coastal waters (will } \\
\text { enter into force in } \\
\text { 2015) }\end{array}$ & \multirow{3}{*}{$\begin{array}{l}\text { A variety of 'green } \\
\text { shipping' rating } \\
\text { schemes; Trident } \\
\text { Alliance of ship- } \\
\text { owners lobby from } \\
\text { strong enforcement } \\
\text { of SECA }\end{array}$} & \multirow{3}{*}{ None } \\
\hline & $\begin{array}{l}\text { IMO MARPOL } \\
\text { Convention: Global } \\
\text { reduction of fuel- } \\
\text { sulphur content } \\
\text { (planned for } 2020 \text { or } \\
2025 \text { ) }\end{array}$ & & \\
\hline & $\begin{array}{c}\text { IMO MARPOL } \\
\text { Convention: Regional } \\
\text { limits to NOx } \\
\text { emissions(NECA) in } \\
\text { North American } \\
\text { coastal waters (will } \\
\text { enter into force in } \\
\text { 2016) }\end{array}$ & & \\
\hline $\begin{array}{l}\text { Invasive } \\
\text { species }\end{array}$ & $\begin{array}{l}\text { IMO Ballast Water } \\
\text { Management } \\
\text { Convention (different } \\
\text { regional rules) }\end{array}$ & None & None \\
\hline
\end{tabular}

Reduction of emissions of sulphur oxides (SOx), nitrogen oxides (NOx), and particulate matter (PM) are also means of achieving environmental upgrading. These are sources of major concern due to their effects on human health and marine environments, in particular close to densely populated areas such as port cities (Corbett et al., 2007; van Aardenne et al., 2013; Tzannatos, 2010). To reduce SOx emissions, regional regulation for the Baltic and North Sea and North American coastal waters entered into force in 2015. A global reduction of fuel-sulphur content is planned in 2020, but may be postponed five years subject to the availability of such fuel. A group of shipping companies have recently started to lobby for 
strong enforcement of the sulphur-regulation, fearing that weak enforcement will result in an un-level playing field (Trident Alliance 2014). SOx emissions further illustrate the regulatory uncertainty regarding environmental deadlines and enforcement in international shipping. Furthermore, NOx emissions have yet to be regulated. They fall under the IMO MARPOL Convention, and regional limits to NOx emissions have been proposed to enter into force in 2016 (IMO, 2014a).

Several studies have also established the link between global shipping and the problems caused by invasive marine species. Non-native species, transported in ships' ballast water tanks and on the outside of ship hulls, can cause great damage to marine ecosystems (Molnar et al., 2008; Bax et al., 2003; DiBacco et al., 2011; Briski et al., 2012; Chan et al., 2013). In order to avoid further damage by invasive species, the IMO adopted the Ballast Water Management Convention in 2004, requiring installation of ballast water treatment systems. However, the treaty has yet to receive ratification, and in the meantime the US has adopted its own set of regional rules, causing large uncertainty in the regulatory framework (IMO, 2014a). ${ }^{2}$

Our interviews with shipping company representatives confirmed that up to a certain level, new regulation is welcomed by the global shipping industry. Regulation to stimulate environmental upgrading via improvements in fuel efficiency in ships, they noted, can constitute a win-win scenario for shipping and society. Interviewees reinforced that reduced fuel consumption leads to lower fuel costs and lower $\mathrm{CO}_{2}$ emissions, so this issue is less controversial than regulation that seeks to stimulate other forms of environmental upgrading. Market-based measures to reduce $\mathrm{CO}_{2}$-emissions however remain controversial among the global shipping industry community as confirmed by the divergence in our interviewee responses (some supportive and others not) and as documented in the literature (Asariotis et al., 2013; BIMCO 2014). In relation to regulation for SOx and NOx, company interviewees uniformly argued that such initiatives would add considerable costs and complexity to their operations, in particular if implemented regionally. The lobbying position of the International Chamber of Shipping against these new regulations aligns with the interviewee responses (ICS, 2014). Across all environmental issues, shipping company interviewees stressed the importance and need for better international regulatory clarity and certainty.

\subsection{Cooperation}

Our shipping company interviews revealed that uncertainties regarding regulatory environmental protection standards are historically high today. For example, as a dry bulk shipping company executive argued: 'Not to sound negative, but I have seen too much reach the IMO level. It takes incredibly long to agree on anything. It's a nightmare. When agreement is finally reached, implementation often turns out to be impossible in real life., ${ }^{3}$ At the same time, shipping companies are faced with other pressures. They need to assess whether to sign up to voluntary industry-led or multi-stakeholder initiatives that also seek to facilitate environmental upgrading in shipping. And some of them are facing increasing pressure from their cargo-owner customers to either report or act on selected environmental issues (see below).

Groups such as the industry-led Clean Cargo Working Group (CCWG) and the NGO-led Sustainable Shipping Initiative (SSI) are providing collaborative fora to educate and encourage the industry towards environmental improvements and, along with green rating schemes, are developing performance metrics to rank and reward companies for better performance (Coady et al., 2013). The CCWG was formed in 2003 by Business for Social 
Responsibility (BSR) and includes cargo-owners and shipping companies as members. It aims at improving the transparency and environmental performance of container ships and shipping companies. Interviewees described the SSI, on the other hand, as a 'lighthouse', not in developing standards but rather in providing a vision and future direction for sustainable shipping efforts. ${ }^{4}$ SSI was established by the Forum for the Future and includes the participation of the WWF as well as cargo-owners (e.g. Unilever) and shipping companies. The SSI aims to inspire the IMO and other regulators to advance greener shipping practices.

Several tools have recently emerged from voluntary green shipping programs for environmental benchmarking of ships and shipping companies, and they differ in several respects (Pike et al., 2011). Some schemes allow shipping companies and cargo-owners to benchmark individual vessels. Other schemes are used as inputs for port authorities' green incentive schemes. Some schemes include a broad spectrum of environmental aspects, and others have a narrow focus on $\mathrm{CO}_{2}$ emissions. Some schemes use absolute data (e.g., $\mathrm{CO}_{2}$ emitted per mile travelled by a 20 foot container), while others rely on a scoring framework based on weighted averages or step ratings, or provide a simple 'pass' or 'fail' evaluation. Some are based on primary performance data reported by shipping companies while others are based on vessel design specifications. And finally, while some require third party data verification (typically by ship classification societies), most datasets are based on selfassessment by shipping companies and are consequently of variable quality.

Some shipping companies are considering whether to use the Carbon Disclosure Project (CDP) for aggregated carbon data to compare company performance as an indicator of shipping company responsibility and commitment to environmental stewardship. Several interviewees stressed, however, that while the CDP can play a role in encouraging corporate transparency and accountability in the shipping sector, it is not a green shipping rating scheme and should not be used to rank and compare shipping companies. ${ }^{5}$

Interviewees were interested in, but also had major reservations about these green rating schemes. Many interviewees highlighted that they felt confused by the wide variety of schemes, lack of standardization and verification of measures, inconsistency of data collection methodology and ranking, and were concerned about the inherent difficulty of shaping uniform measures across a very diverse industry. ${ }^{6}$

In addition to an uncertain regulatory framework and a confusing set of industry and stakeholder initiatives, shipping companies are also increasingly under pressure from cargoowners (their clients) to improve selected elements of environmental performance. To understand this dynamic, we examine: first, the governance and environmental upgrading potential in the three main segments of maritime shipping; and second, the cargo-owners' own environmental commitments, including whether they include aspects related to maritime shipping.

\subsection{Buyer demands}

The potential and limitations of buyer-driven environmental upgrading in shipping can be revealed in the governance dynamics across the three major segments of the industry. The dry bulk, tanker and container shipping segments have different characteristics that shape the power relationships between cargo-owners and shipping companies. This includes differences in: type of cargo, trade distribution patterns, market concentration and ownership, contract length, and bargaining power dynamics (see Table 2). 
Table 2: Comparison of Maritime Shipping Segments

\begin{tabular}{|c|c|c|c|}
\hline & Dry bulk & Tanker & Container \\
\hline $\begin{array}{l}\text { Size of fleet } \\
\text { (million dead- } \\
\text { weight tons) }^{1}\end{array}$ & 685 & 491 & 207 \\
\hline $\begin{array}{l}\text { Market } \\
\text { concentration } \\
\text { (top } 3 \text { shipping }^{\text {companies) }}{ }^{2} \\
\end{array}$ & $\begin{array}{l}\text { 'Perfect } \\
\text { competition' }\end{array}$ & $\begin{array}{l}\text { Top 3: 9 \% } \\
\text { Mitsui-OSK } \\
\text { (MOL), NITC, } \\
\text { NYK }\end{array}$ & $\begin{array}{l}\text { Top 3: } \sim \mathbf{3 0 \%} \\
\text { Maersk, MSC, CMA } \\
\text { CGM } \\
\text { Top 5: } \sim \mathbf{4 6 \%}\end{array}$ \\
\hline $\begin{array}{l}\text { Goods shipped } \\
\text { (inbound and } \\
\text { outbound) }\end{array}$ & $\begin{array}{l}\text { Inert Cargo } \\
\text { - Outbound coal, } \\
\text { iron ore, grain, } \\
\text { bauxite/aluminum, } \\
\text { phosphate rock etc. }\end{array}$ & $\begin{array}{l}\text { High risk cargo } \\
\text { - Outbound oil \& } \\
\text { gas, chemicals }\end{array}$ & $\begin{array}{l}\text { High value cargo } \\
\text { - Inbound } \\
\text { materials/intermediate } \\
\text { goods and outbound } \\
\text { finished goods }\end{array}$ \\
\hline Trade pattern & $\begin{array}{l}\text { Single load and } \\
\text { destination. }\end{array}$ & $\begin{array}{l}\text { Single load and } \\
\text { single destination. }\end{array}$ & $\begin{array}{l}\text { Fixed route: Time } \\
\text { sensitive scheduled } \\
\text { liner services. Vessels } \\
\text { loading and } \\
\text { unloading various } \\
\text { cargoes at various } \\
\text { ports }\end{array}$ \\
\hline Customers & $\begin{array}{l}\text { Many: } \\
\text { Large MNCs such } \\
\text { as Cargill and } \\
\text { numerous smaller } \\
\text { companies }\end{array}$ & $\begin{array}{l}\text { Very few: } \\
\text { Major MNCs such } \\
\text { as Shell, Exxon. } \\
\text { Many own their } \\
\text { own vessels. }\end{array}$ & $\begin{array}{l}\text { Many: } \\
\text { Large retailers; third } \\
\text { party logistics } \\
\text { providers; and many } \\
\text { small companies }\end{array}$ \\
\hline Contract length & Varies & Varies & Short term \\
\hline GVC governance & $\begin{array}{l}\text { Very little explicit } \\
\text { governance: low } \\
\text { levels of driving; } \\
\text { viewed closed to a } \\
\text { 'perfect } \\
\text { competition' } \\
\text { market, extremely } \\
\text { price sensitive }\end{array}$ & $\begin{array}{l}\text { Unipolar } \\
\text { governance; } \\
\text { highly-driven by } \\
\text { oil majors }\end{array}$ & $\begin{array}{l}\text { Bipolar governance; } \\
\text { with current market } \\
\text { overcapacity, cargo- } \\
\text { owners have some } \\
\text { bargaining power, but } \\
\text { this is limited by high } \\
\text { concentration in } \\
\text { shipping }\end{array}$ \\
\hline $\begin{array}{l}\text { Environmental } \\
\text { upgrading focus }\end{array}$ & None & $\begin{array}{l}\text { High, but } \\
\text { exclusive focus on } \\
\text { oil spills (history } \\
\text { of Exxon Valdez } \\
\text { spill) }\end{array}$ & $\begin{array}{l}\text { Emerging on } \mathrm{CO} 2 \\
\text { emissions; future } \\
\text { expected concerns } \\
\text { with } \mathrm{SOx}, \mathrm{NOx} \text {, and } \\
\text { ballast water }\end{array}$ \\
\hline
\end{tabular}

\footnotetext{
${ }^{1}$ UNCTAD Review of Maritime Transport 2013, UNCTAD, p. 36, Available online at: http://unctad.org/en/publicationslibrary/rmt2013 en.pdf. In 2013, the world fleet represented a total of 1,629 million deadweight tons.

${ }^{2}$ Alphaliner (2013) Top 100 Operated Fleets. Available online from: www.alphaliner.com/top100 (measured in TEU capacity) and "TANKEROperator's Top 30 owners and operators", March 2014 (measured in deadweight tonnes).
} 
Dry bulk carriers, tankers and container ships transport different cargo types and trade in different patterns. The first two vessel types typically transport one type of cargo for one cargo-owner per voyage and generally carry cargo with a low value per weight. In dry bulk shipping, the main cargo types are coal, iron ore, grain, bauxite/aluminium and phosphate rock, while in tanker shipping they are crude oil, various refined oil products, chemicals and various gases. Typically, these ships operate from port to port, wherever cargo is available (Gratos, et al., 2012; Lyridis, 2012; Stopford, 2009). In contrast, container vessels operate scheduled liner services, transporting different types of cargo for different cargo-owners on the same voyage. Calling at many ports en route, container ships carry cargo of higher value per weight than dry bulk vessels and tankers. Containerized cargo includes consumer goods (such as apparel, electronics and food) and various semi-manufactured products. Some of the containerized cargo is time sensitive and has high inventory costs (e.g. fast fashion, electronics). Most containerized cargo is ready for distribution and retail upon arrival in port, whereas most dry and liquid bulk cargo needs considerable processing before it reaches consumers (Stopford, 2009; Notteboom, 2012).

In terms of GVC governance, dry bulk shipping is characterised by diffuse, low levels of either buyer or supplier 'driving' influence and is often referred to as a textbook example of 'perfect competition' (Stopford, 2009; Gratsos et al., 2012). Entry barriers are low, transport services are highly commoditized, and the freight market is transparent, with numerous buyers and sellers. In some instances, dry cargo-owners and shipping companies enter into long-term contracts, but in most cases the two parties meet only once in the marketplace, negotiating transportation for a single voyage. Indeed, dry bulk shipping company interviewees unanimously stated that price is cargo-owners' paramount priority and the environmental footprint is generally not taken into consideration. Cargo needs considerable processing before it reaches consumers, and to the extent that consumers have green preferences, they do not seem to reach upstream to dry bulk (and tanker) shipping. Moreover, several shipping company interviewees emphasize that many dry bulk cargoowners do not have a CSR or sustainability policy, and therefore never ask shipping companies questions related to environmental performance. As a dry bulk shipping interviewee, who works in chartering, stated: 'A ... man in Indonesia, who owns a mine, only cares about the freight rate ... He does not care at all about $\mathrm{CO}_{2}$ emissions. ${ }^{7}$ When asked specifically about green rating schemes, he replied: 'This is not something I've ever touched upon. ${ }^{8}$ Another dry bulk interviewee, in an executive position, agreed, and mentioned an example of a 40,000-ton briquettes shipment: 'There is no marketing value in saying that you have sailed all the way to Australia in an extremely green mode. And subsequently you burn the briquettes, ${ }^{9}$ Therefore, buyer-driven pressure on environmental upgrading in this shipping segment is minimal. We also asked interviewees in dry bulk shipping companies about their expectations of what cargo-owners may require from them in the future. Here answers differed: the vast majority of interviewees remain sceptical that cargo-owners will start asking these questions given the business-to-business nature of their interactions. ${ }^{10}$ However, a few say that these questions may come at a later stage, and have now formulated corporate sustainability policies. ${ }^{11}$ One dry bulk shipping company CEO argued specifically for regulation to address climate change. He stated: 'as seen from a broader environmental perspective, focused on the best for the world... some practices should be regulated... A schism... exists. For society, the mitigation of a temperature increase and reduction of pollution will be a benefit. However, more narrow economic interests may go in the opposite direction. Regulation is necessary, and it should apply to everyone, to create a level playing field... This is what the IMO does, regulates practices. ${ }^{, 12}$ 
In tanker shipping, cargo-owners are mainly oil majors and various commodity traders (Stopford, 2009; Lyridis and Zacharioudakis, 2012). Due to their size, multinational oil corporations are very powerful cargo-owners, and historically have often vertically integrated tanker shipping into their operations. While some of the oil majors continue to own and operate (as well as lease) their own fleets, the main share of the world tanker fleet is now owned by independent ship-owners. Some vessels operate on long-term charters for oil majors, while other vessels operate in the spot market with charters of short duration (Stopford, 2009). Overall, this segment of the shipping industry can be characterised as unipolar, in terms of being highly-driven by buyers (oil majors). As a result, buyers have been able to shape the environmental agenda to meet their concerns, which are exclusively focused on safety. ${ }^{13}$ Oil spills are a major concern in tanker shipping, with the Exxon Valdex's oil-spill in Alaska in 1989 seen as a global turning point for tanker safety. According to all our tanker interviewees, oil majors have been major drivers of tanker shipping safety standards ever since, in some respects moving beyond IMO regulation. To support this drive, each oil major has developed its own auditing scheme (called 'vetting'). Tankers are audited in frequent on-board inspections by oil majors, and safety and training procedures in the shipping company are also scrutinized on-shore. No interviewees in tanker shipping companies currently see any pressures from oil majors in relation to other environmental concerns in shipping. For instance, problems related to air emissions or ballast water do not appear in the vetting schemes of any oil major, and in the absence of regulation no interviewee expects any change in this realm in the near future. ${ }^{14}$ An executive summed up the prevailing attitude in tanker shipping: ' ...the crucial thing for oil majors is safety. The worst thing would be... an oil spill... Ship-owners' $\mathrm{CO}_{2}$ emissions as a procurement criteria for customers? I don't see that happening., ${ }^{15}$

In container shipping, the relationship between cargo-owners and shipping companies has a more balanced nature. On the demand side, cargo-owners of widely variable size, including retailers, manufacturing companies and branded agro-food processors, contract both inbound and outbound shipments. Although they wield power, even the largest cargo-owners - such as multinational retailers like Walmart - do not dominate the container shipping market. Third party logistics providers consolidate cargo from small cargo-owners, and negotiate freights with shipping companies on behalf of these cargo-owners. They do so in order to achieve economies of scale, which small cargo-owners cannot gain on their own (SkjoettLarsen, 2000; Hertz and Alfredsson, 2003; Bolumole, 2011; Coe, 2014). On the shipping company supply side, the concentration ratio has increased over time. Currently, the top five and top twenty container shipping companies currently operate respectively 46 and 85 per cent of the global container fleet capacity, although the level of concentration varies between trade-lanes (Alphaliner, 2014). ${ }^{16}$ But despite the increasing market power of shipping companies, during our fieldwork period (2012-2014) excess capacity prevailed, and shipping companies were competing more than ever to find cargo to fill their under-utilized vessels. Price, transit time, schedule reliability, frequency, free capacity for bookings at the last moment before departure and spatial coverage of liner shipping networks are the typical priorities for containerized cargo-owners. In order to minimize supply chain risks, the cargoowners we interviewed prefer to ship their cargo with at least two or three different shipping companies. Contracts are generally negotiated annually. This segment of shipping is thus currently characterised by bipolar governance, with levels of driving divided between powerful cargo-owner buyers and shipping service suppliers, and falling in between those observed in dry bulk (low) and tanker shipping (high). 
Given this bipolar governance structure, to what extent are cargo-owners developing and transmitting environmental demands to container shippers? Cargo-owners making use of container shipping services include many small to medium-sized companies trading products, materials and components as well as major brand companies in the consumer goods, retail, apparel, home improvement and electronics sectors. ${ }^{17}$ These companies depend on customer loyalty and good brand reputation. In recent years, in response to growing consumer environmental concerns as well as increasing costs and reduced demand with the global financial crisis, brand companies have embraced environmental upgrading as a new business strategy to reduce risk, gain supply chain control and increase sales (Dauvergne and Lister, 2013). They have introduced aspirational company commitments including zero carbon, zero waste and $100 \%$ renewable energy, not just in their own operations but also with their suppliers and along the entire value chain. This is now slowly moving to shippingrelated concerns. Some cargo-owners have started to ask questions or place requirements to shipping companies, depending on the value and nature of their inbound and outbound cargoes (inventory costs and time sensitivity). ${ }^{18}$ As one interviewee highlighted, 'although transportation is a fraction of their business, ... [cargo-owners] are starting to push to set new standards - they have this power and they are giving ideas to others. ${ }^{19}$

Brand company interest in environmental upgrading of transport appears to be accelerating and expectations are becoming more specific. A survey in 2008 of over 1,500 logistics executives identified 98 per cent support for the belief that environmental upgrading initiatives will be somewhat or very important to their companies' futures. They agreed that doing nothing was not an option, but had a high level of uncertainty as to how to move forward (Langley, 2009: 4-5). Two years later in 2010, brand company customers were more informed, identifying that along with lower costs and increased efficiency and reliability, they would be seeking reduced environmental risk from their container shipping lines (Pruzan-Jorgensen, 2010:15). And in 2012, the environmental concerns of brand companies had become more specific - 52 percent of cargo-owners (of 2,342 industry executives surveyed) identified fuel efficiency and $\mathrm{CO}_{2}$ emissions as an important part of their third party logistics procurement decision processes (Langley, 2013:11).

To assess the extent to which brand companies are sensitive to potential environmental upgrading in maritime shipping more specifically, we conducted a desk review of the CSR/sustainability reports of the top-ten US container import customers (JOC, 2012). In this review, we focused on the issue of emissions and evaluated: first, whether the company had made a commitment to GHG reductions; second, whether this included mention of transportation (distribution and logistics); and finally, whether maritime shipping was addressed and if so, what actions were being taken (see Table 3).

We found that virtually all companies (nine out of ten) reported a corporate commitment to GHG (carbon) reduction, with transport as a target within their overall carbon reduction goal. With respect to transport, the focus for the most part is on improving fuel efficiency in trucking and on $\mathrm{CO}_{2}$ reduction. Only four out of ten addressed maritime shipping. Specific commitments and activities reported included: product life cycle assessment of carbon footprint from ocean transit (Chiquita); measuring and certifying carbon management (Dole); switching cargo from air to ship (Philips Electronics), truck to ship (Heineken) and from reefer to container vessel (Chiquita) to reduce emissions and increase fuel efficiency; updating ships with fuel efficiency systems (Dole); optimizing container usage (Philips Electronics); and Scope 3 reporting ${ }^{20}$ on GHG emissions to the Carbon Disclosure Project (Philips Electronics). 
Table 3: US Container Importer Commitment to Sustainable Maritime Transport

\begin{tabular}{|c|c|c|c|c|}
\hline $\begin{array}{l}\text { Top Ocean } \\
\text { Container } \\
\text { Importers to US }\end{array}$ & $\begin{array}{r}\text { TEU } \\
2012 *\end{array}$ & $\begin{array}{c}\text { Carbon } \\
\text { commitment? }\end{array}$ & $\begin{array}{c}\text { Address } \\
\text { transport? }\end{array}$ & $\begin{array}{c}\text { Address } \\
\text { maritime } \\
\text { shipping? }\end{array}$ \\
\hline \multirow{6}{*}{$\begin{array}{l}\text { 1. Walmart } \\
\text { 2. } \text { Target }^{1,2} \\
\text { 3. Home Depot } \\
\text { 4. Dole Food } \\
\text { 5. Lowe's } \\
\text { 6. Sears Holding }\end{array}$} & 720,000 & YES & YES & $\mathrm{X}$ \\
\hline & 496,200 & YES & YES & $\mathrm{X}$ \\
\hline & 315,400 & YES & YES & $\mathrm{X}$ \\
\hline & 235,000 & YES & YES & YES \\
\hline & 229,000 & YES & YES & $\mathrm{X}$ \\
\hline & 201,500 & $\begin{array}{c}\text { Under } \\
\text { development }\end{array}$ & $\mathrm{X}$ & $\mathrm{X}$ \\
\hline \multirow{4}{*}{$\begin{array}{l}\text { 7. Chiquita } \\
\text { 8. LG Group } \\
\text { 9. Heineken }{ }^{1,2} \\
\text { 10. Philips Elec } \\
\text { 1, 2,3 }\end{array}$} & 149,400 & YES & YES & YES \\
\hline & 147,300 & YES & YES & $\mathrm{X}$ \\
\hline & 144,800 & YES & YES & YES \\
\hline & 124,700 & YES & YES & YES \\
\hline \multicolumn{2}{|c|}{$\%$ Commitment } & $90 \%$ & $90 \%$ & $40 \%$ \\
\hline
\end{tabular}

*Source: Journal of Commerce (2012).

${ }^{1}$ Members of the Clean Cargo Working Group (CCWG)

${ }^{2}$ Report GHG emissions to the Carbon Disclosure Project (CDP)

${ }^{3}$ Also report Scope $3 \mathrm{GHG}$ emissions to CDP

It is of note that of the four companies that did address environmental issues in maritime shipping in their reports, both Dole Food and Chiquita own their own vessels, while Heineken and Philips Electronics are members of CCWG. Walmart is also a member of CCWG but did not report on any carbon reduction commitments or efforts related to maritime shipping (which they contract out). The company focused solely on sustainable transportation improvements in trucking (where they own the fleet). Finally, while several members report to the Carbon Disclosure project on their GHG emissions, only Philips includes reporting on Scope 3 emissions (although it is not clear whether this includes inbound and outbound transport).

The picture we provide on container shipping suggests that brand company cargo-owners have committed to carbon reductions within their organization and most include transportation as a target, but most are not yet explicitly addressing the carbon impact of maritime shipping. Those that own their own vessels or are members of CCWG (with the exception of Walmart) are leading in the communication of commitments and efforts in sustainable maritime shipping. While many brand companies are members of the Carbon Disclosure Project, they are not yet tracking and reporting emissions from distribution and logistics of inbound and outbound maritime shipping. Other environmental upgrading issues related to maritime shipping discussed earlier (such as SOx, NOx and invasive species) are not specifically addressed in company CSR/sustainability reports.

\section{Key issues and main limitations of buyer-driven environmental upgrading}


The overall picture of governance and environmental upgrading in shipping varies according to its different segments. In dry-bulk, lack of predominant buyer or supplier power and hence, low levels of driving, coupled with low consumer visibility of the product transported, has hindered buyer-driven environmental upgrading. In tanker shipping, a unipolar and highly-driven governance structure, with oil majors as lead firms, have led to significant but narrowly defined environmental improvements, almost exclusively in relation to oils spills. Container shipping transports goods that are much closer to the end-consumer than dry bulk or tanker vessels, which ship raw materials. As such, buyer demands for environmentally responsible shipping could be expected to be most pronounced in this segment than in dry bulk and tanker shipping. Cargo-owners in the container segment of the shipping industry are indeed furthest along this road and have starting to ask questions about shipping companies' environmental upgrading performance. Some are requesting increasingly detailed environmental data and are planning to introduce environmental audits of their shipping companies. However, most do not yet follow up on this information or use it. Only a few cargo-owners have so far attempted to integrate sustainability into procurement decisions and contracting. As our interviewees revealed, price and reliability continue to be the essential contractual considerations. 'All [cargo-owners] want to integrate [sustainability concerns] but none wants to pay more,' we were told. ${ }^{21}$ When asked why they are not integrating environmental performance into their contracting, one cargo-owner explained: 'our margin is only three, four and half per cent, so we need to focus on cost. Service and sustainability are factors beyond this. ${ }^{22}$ In relation to $\mathrm{CO}_{2}$ emissions, it was further noted that 'there isn't a big difference between shipping companies on $\mathrm{CO}_{2}$ performance so it is not playing a role yet in procurement decisions. ${ }^{23} \mathrm{In}$ sum, cargo-owners have concerns about $\mathrm{CO}_{2}$ emissions and are important potential drivers of environmental upgrading in maritime shipping, but there are also limitations deterring progress.

First, the bipolar governance structure of container shipping has limited the full transmission of budding buyer-driven environmental concerns. Although cargo-owners can exert substantial power, the container shipping industry is highly concentrated and also powerful, with five major shipping companies accounting for the majority of cargo transported. Therefore, cargo-owners are limited to wielding their upgrading influence by threatening to shift volume from one carrier to another rather than dropping shipping companies for poor performance.

Second, many cargo-owners lack knowledge on environmental topics related to shipping, especially beyond a narrow take on $\mathrm{CO}_{2}$ emissions. Some of the major container shipping companies are now working to increase the cargo-owner knowledge of environmental issues, as part of reinforcing business relationships with them. For example, one of the major shipping companies has developed a 'carbon pact' with a producer of consumer goods to help them achieve their carbon reduction targets from transport. This shipping company has also developed a customer rating scale on the extent to which cargo-owners are asking for and incorporating environmental considerations into their procurement decisions. In an interview with this company, we were told that cargo-owners representing $21 \%$ of container volumes are asking questions about environmental performance, but only one-to-three have fully integrated $\mathrm{CO}_{2}$ considerations into their contracts. The interviewee explained that 'environmental issues are affecting the business relationship, but not connecting yet to a change in business practice. 24

Third, there is a lack of a consistent carbon measurement standard to enable evaluation of performance and benchmarking comparison. Still, cargo-owners are pressuring shipping 
companies to join the CCWG and adopt its standardized carbon measurement tool so that cargo-owners can have credible data. A sign that this is making a difference is that sixteen out of top twenty container shipping companies have now joined the CCWG.

Fourth, cargo-owners with explicit environmental upgrading policies tend to focus on their main $\mathrm{CO}_{2}$ emission sources. In many cases, maritime shipping accounts only for a small share of their total emissions and thus, it tends to be ignored. As long as cargo-owners see greater savings potential elsewhere in their supply chains, they are likely keep their main focus there. The cargo-owners we interviewed estimate that less than five per cent of their $\mathrm{CO}_{2}$ emissions are attributable to maritime shipping.

Fifth, shipping accounts for a higher share of other emission types (12 and 13 per cent of global SOx and NOx emissions, respectively; IMO 2014b), but only $\mathrm{CO}_{2}$ emissions and fuel efficiency are current environmental upgrading priorities among cargo-owners. NOx and SOx emissions and ballast water management are expected to become more important in the near future, and a few shipping companies are preparing to address these. A representative of a green shipping multi-stakeholder initiative, however, stated that many shipping companies are not prepared at all for the upcoming environmental demands that cargo-owners may place on them, and that this 'is going to hit them unexpectedly and devastatingly for their business competitiveness. ${ }^{25}$

Sixth, all interviewees in shipping companies emphasized the additional costs involved in meeting new environmental standards and demands. Shipping is a highly cyclical industry that operates on small margins. Interviewees pointed out that although there is a business case for fuel efficiency, environmental upgrading is expensive, and ultimately consumers will need to pay. While cargo-owners are asking questions to their container shipping companies and making commitments to reduce the environmental footprint of transportation within their value chains, price remains their priority decision-making factor. One interviewee went through the numbers, showing us how costs per tonne of fuel will increase by 50 per cent for SOx and NOx compliance. ${ }^{26}$ Another ship-owner explained that 'ballast management will cost hundreds of thousands of dollars per ship for retrofitting. We don't have the cash [for it]. ${ }^{27}$ Simmering tensions between shipping companies and brand company cargo-owners were also reported. On the one hand, low cost is a cargo-owners' main business driver. On the other hand, they are demanding environmental upgrading. Finding means to achieve cost savings and environmental upgrading beyond fuel efficiency will remain a major challenge.

Finally, many interviewees explained that while voluntary efforts are moving ahead, real change will not come without international regulation, state intervention or incentives. 'There have to be incentives or no one will do anything,' a ship-owner declared. ${ }^{28}$ 'The big breakthrough will come from government in the future even though private efforts are leading now,' another interviewee stressed. ${ }^{29}$ In other words, buyer-driven environmental upgrading is not likely to make a substantial difference unless it is supported by clear, stable and enforceable global regulation.

\section{Conclusion}

Global shipping causes considerable environmental problems to marine environments, global climate and human health, and its environmental upgrading performance lags behind other industrial sectors. International regulation of shipping remains difficult and major 
uncertainties accompany implementation, deadlines and enforcement of every new piece of IMO legislation. Moreover, regional and unilateral regulation has started to emerge, adding further complexity to global shipping operations. Without the explicit governance traits of either strong buyer or supplier power, environmental upgrading is fundamentally absent in dry-bulk shipping. In tanker shipping, oil majors are the lead buyer firms and have shaped environmental concerns narrowly on oil spills. In both segments, lack of a direct link between the goods transported and the final consumer slows further (or broader) environmental upgrading.

In container shipping, where the goods transported are often branded consumer goods, cargo-owners are starting to place demands on, or at least ask questions to, shipping companies regarding their environmental performance. This is occurring in the context of the emergence of industry-led and multi-stakeholder initiatives on sustainable shipping and a variety of green rating schemes. However, cargo-owners' efforts have only just started, and their focus is so far mainly on $\mathrm{CO}_{2}$ emission and fuel efficiency, largely ignoring other significant environmental problems in shipping. Only a few cargo-owners have begun to integrate environmental performance into their procurement decisions in relation to shipping company selection, and even fewer have included these considerations into pricing models. Furthermore, those who have done so are hindered by a bipolar governance structure of strong buyer and supplier power that diffuses the potential for a complete 'buyer-driven' transmission of environmental demands onto shipping companies. Expectations among shipping companies and cargo owners (branded retailers and manufacturers) are that environmental demands will continue to develop, strengthen and expand. Yet, barriers are hampering environmental upgrading. Closer alignment of the voluntary 'green shipping' initiatives with the IMO, EU and state regulatory requirements is seen as essential to drive further improvements.

More generally, our case study of maritime shipping suggests the current limitations to 'buyer-driven' environmental upgrading. While in other industries, such as furniture, we can observe both 'standard-driven' greening led by buyers and more cooperative 'mentoringdriven' greening (De Marchi et al., 2013), cargo-owners have not (yet) developed sophisticated environmental demands - nor have they placed them at the core of negotiations regarding the procurement of shipping services. Limited environmental upgrading, even in the more forward-looking container segment of shipping, is also attributed to relatively balanced power relations between cargo-owners and shipping companies - with the latter mainly interested, for the time being, in environmental measures that lead to cost-savings (mainly, lower fuel consumption).

More generally, the findings of our research suggest that environmental upgrading is more likely to happen in GVCs characterised by unipolar governance and where the lead firms are consumer-facing companies with reputational risks. It is also more likely to happen where international regulation is clearly defined and enforced, and where mutual recognition, benchmarking and similar measurement systems characterise industry and multi-stakeholder sustainability initiatives.

Future research opportunities include the need to track and evaluate the evolving dynamics of governance in the three shipping segments, and especially whether possible changes in the balance of power in container shipping (with industry re-structuring and cyclical market fluctuations) lead to alterations in environmental upgrading trajectories. Additionally, it will be important to monitor whether the potential emergence of consumer-facing labels on the environmental impact of various transport options facilitates 'buyer-driven greening' in the 
shipping industry. More broadly, far more GVC-inspired research is needed on environmental upgrading trajectories and their drivers, and especially on the interaction between service providers and GVC operators. And finally, there is an essential research need to better understand and ensure the accountability and alignment of voluntary marketbased private governance green shipping initiatives with public regulation.

\section{References}

Acciaro, M., Hoffman, P.N., Eide, M.S. (2013) The energy efficiency gap in maritime transport. Journal of Shipping and Ocean Engineering, 3:1-10.

Alphaliner (2014), Alphaliner - TOP 100 - Operated fleets as per 15 July 2014 [Homepage of Alphaliner]. Available online at: http://www.alphaliner.com/top100/. [Accessed 15 July 2014].

Anderson, K., Bows, A. (2012) Executing a Scharnow turn: reconciling shipping emissions with international commitments on climate change. Carbon Management, 3:615-628.

Asariotis, R., Benamara, H., Hoffman, J.H., Jaimurzina, A., Premti, A. Buriato, J.M., Valentino, V., Youssef, F. (2013) Review of Maritime Transport 2013. Geneva: United Nations Conference on Trade and Development.

Bair, J. (ed) (2009) Frontiers of commodity chain research. Stanford: Stanford University Press.

Barrientos, S. (2013a) 'Labour chains': Analysing the role of labour contractors in global production networks. The Journal of Development Studies, 49:1058-1071.

Barrientos, S. (2013b) Corporate purchasing practices in global production networks: A socially contested terrain. Geoforum, 44:44-51.

Barrientos, S., Gereffi, G., Rossi, A. (2010) Economic and social upgrading in global production networks: developing a framework for analysis. Capturing the Gains Working Paper 2010/03. Available online from: http://www.capturingthegains.org/pdf/ctg-wp-201003.pdf [Accessed 09 September 2014].

Barrientos, S., Gereffi, G., Rossi, A. (2011) Economic and social upgrading in global production networks: a new paradigm for a changing world. International Labour Review, 150: 319-340.

Bax, W., Williamson, A., Aguero, M., Gonzalez, E., Geeves, W. (2003) Marine invasive alien species: a threat to global biodiversity. Marine Policy, 27:313-323.

Bazari, Z., Longva, T. (2011) Assessment of IMO mandated energy efficiency measures for international shipping. Project Final Report, 31. Llyods Register and DNV.

Bolumole, Y.A. (2001) The supply chain role of third-party logistics providers. International Journal of Logistics Management, 12:87-102. 
Briski, E., Ghabooli, S., Bailey, S.A., Macisaac, H.J. (2012) Invasion risk posed by macroinvertebrates transported in ships' ballast tanks. Biological Invasions, 14:1843-1850.

Buhaug, Ø., Corbett, J., Endresen, Ø., Eyring, V., Faber, J., Hanayama, S., Lee, D., Lindstad, H., Markowska, A. (2009) Second IMO GHG study. London: International Maritime Organization. Available online at: http://www.imo.org/OurWork/Environment/PollutionPrevention/AirPollution/Pages/Greenh ouse-Gas-Study-2009.aspx [Accessed 09 September 2014].

Burgherr, P. (2007) In-depth analysis of accidental oil spills from tankers in the context of global spill trends from all sources. Journal of hazardous materials, 140:245-256.

Cattaneo, C., Gereffi, G., Staritz, C. (eds) (2010) Global value chains in a postcrisis world. Washington: World Bank.

Cattaneo, C., Gereffi, G., Miroudot, S., Taglioni D. (2013) Joining, upgrading and being competitive in global value chains: a strategic framework. Washington: World Bank Policy Research Working Paper.

Chan, F. T., Bailey, S. A., Wiley, C. J., MacIsaac, H. J. (2013) Relative risk assessment for ballast-mediated invasions at Canadian Arctic ports. Biological Invasions, 15: 295-308.

Coady, L., Lister, J., Strandberg, C., Ota, Y. (2013) The Role of Corporate Social Responsibility in the International Shipping Sector. Vancouver: Liu Institute for Global Issues. Available online from:

http://www.ligi.ubc.ca/sites/liu/.../CSRShippingWorkshopProgramFinal.pdf .[Accessed 10 September 2014].

Coe, N.M. (2014) Missing links: logistics, governance and upgrading in a shifting global economy. Review of International Political Economy, 21:224-256.

Coe, N.M., Hess, M. (2013a) Economic and social upgrading in global logistics. Capturing the Gains Working Paper, No. 38. University of Manchester. Available online at: https://www.escholar.manchester.ac.uk/uk-ac-man-scw:207096. [Accessed 09 September 2014].

Coe, N.M., Hess, M. (2013b) Global production networks, labour and development. Geoforum 44:4-9.

Coe, N.M., Yeung, H.W. (2015). Global production networks: Theorizing economic development in an interconnected world. Oxford: Oxford University Press.

Corbett, J.J., Winebrake, J.J., Green, E.H., Kasibhatla, P., Eyring, V., Lauer, A. (2007) Mortality from ship emissions: a global assessment. Environmental science \& technology, 41:8512-8518.

Danish Shipowners' Association (2012) Green transport of global trade - The Danish shipping industry's initiatives and positions on climate and environmental issues. Copenhagen: Danish Shipowners' Association.`

Dauvergne, P., Lister, J. (2013) Eco-business: a big-brand takeover of sustainability. Cambridge, MA.: The MIT Press. 
De Marchi, V., Di Maria, E., Micelli, S. (2012) Environmental strategies, upgrading and competitive advantage in global value chains. Business Strategy \& the Environment, 22: 6272 .

De Marchi, V., Di Maria, E., Ponte, S. (2013) The greening of global value chains: insights from the furniture industry. Competition and Change, 17:299-318

DiBacco, C., Humphrey, D.B., Nasmith, L.E., Levings, C.D. (2011) Ballast water transport of non-indigenous zooplankton to Canadian ports. ICES Journal of Marine Science 69:483491.

Dicken, P. (2011) Global shift: mapping the changing contours of the world economy, $6^{\text {th }}$ edn. London: Sage; New York: Guildford.

Eide, M.S., Longva, T., Hoffman, P., Endresen, Ø., Dalsøren, S.B. (2011) Future cost scenarios for reduction of ship CO2 emissions. Maritime Policy \& Management, 38(1):1137.

EIO (2013) ET Global 8002013 Carbon Rankings. London: Environmental Investment Organization.

Faber, J., Wand, H., Nelissen, D., Russel, B., St Amand, D. (2011) Marginal Abatement Costs and Cost Effectiveness of Energy-Efficiency Measures. MEPC 62 INF 7.

Fold, N. (2002) Lead firms and competition in 'bi-polar' commodity chains: Grinders and branders in the global cocoa-chocolate industry. Journal of Agrarian Change, 2(2):228-47.

Gereffi, G. (1994) The organization of buyer-driven global commodity chains: How us retailers shape overseas production networks. In G. Gereffi and M. Korzeniewicz (eds.) Commodity Chains and Global Capitalism. Westport: Greenwood Press.

Gereffi, G. (2014) Global value chains in a post-Washington Consensus world. Review of International Political Economy, 21:9-37.

Gereffi, G., and Fernandez-Stark, K. (2011) Global Value Chain Analysis: A Primer.

Durham, NC: Center on Globalization, Governance \& Competitiveness, Duke University.

Gereffi G., Korzeniewicz, M., Korzeniewicz, R. (1994) Introduction: Global Commodity Chains. In G. Gereffi and M. Korzeniewicz (eds.) Commodity Chains and Global Capitalism. Westport: Greenwood Press.

Gereffi, G. (1999) International trade and industrial upgrading in the apparel commodity chain. Journal of International Economics, 48:37-70.

Gereffi, G. and Lee, J. (2014) Economic and Social Upgrading in Global Value Chains and Industrial Clusters: Why Governance Matters, Journal of Business Ethics DOI 10.1007/s10551-014-2373-7

Goger A. (2013) The making of a 'business case' for environmental upgrading: Sri Lanka's eco-factories. Geoforum 47: 73-83. 
Gibbon, P., Ponte, S. (2005) Trading down: Africa, value chains and the global economy. Philadelphia: Temple University Press.

Gibbon, P. (2001) Upgrading Primary Production: A Global Commodity Chain Approach. World Development, 29: 345-363.

Gibbon, P., Bair, J., Ponte, S. (2008) Governing global value chains: An introduction. Economy and Society, 37(3):315-338.

Gratsos, G.A., Thanopoulou, H.A., Veenstra, A.W. (2012) Dry Bulk Shipping. In W.K. Talley (ed) The Blackwell Companion to Maritime Economics. Oxford: Wiley Blackwell.

Hertz, S., Alfredsson, M. (2003) Strategic development of third party logistics providers. Industrial Marketing Management, 32:139-149.

Huijer, K. (2005) Trends in oil spills from tanker ships 1995-2004. London: International Tanker Owners Pollution Federation (ITOPF).

Hummels, D. (2007) Transportation costs and international trade in the second era of globalization. The Journal of Economic Perspectives, 21:131-154.

Humphrey, J., Schmitz, H. (2002) How does insertion in global value chains affect upgrading in industrial clusters? Regional Studies, 36:1017-1027.

ICS (2014) Safety and Environment. International Chamber of Shipping (ICS), Available online from: http://www.ics-shipping.org/key-issues/safety-and-environment [Accessed 07 September 2014].

IMO, 2014a, Homepage of IMO. Available online at: http://www.imo.org/OurWork/Environment/Pages/Default.aspx. [Accessed 09 September 2014].

IMO, 2014b. Third IMO GHG Study 2014, MEPC 67/INF.3, London: IMO.

Islam, M.S. (2009) From pond to plate: Towards a twin-driven commodity chain in Bangladesh shrimp aquaculture. Food Policy, 33:209-223.

Ivarsson I., Alvstam C.G. (2010) Supplier upgrading in the home-furnishing value chain: an empirical study of IKEA's sourcing in China and South East Asia. World Development 38: 1575-1578.

Jafarzadeh, S., Utne, I.B. (2014) A framework to bridge the energy efficiency gap in shipping. Energy, 69:603-612.

Jeppesen S., Hansen W.H. (2004) Environmental upgrading of third world enterprises through linkages to transnational corporations. Theoretical perspectives and preliminary evidence. Business Strategy and the Environment 13: 261-274.

Johnson, H., Andesen, K. (2014) Barriers to energy efficiency in shipping, WMU Journal of Maritime Affairs. 
Journal of Commerce (JOC) (2012) Top 100 importer and exporter ranking, 27 May 2012 Available online from: https://www.joc.com/special-topics/top-100-us-importers [Accessed 09 September 2014].

Kaukiainen, Y. (2014) The role of shipping in the second stage of globalisation. International Journal of Maritime History, 26:64-81

Langley, J. Jr. and Capgemini US LLC (2009) The State of Logistics Outsourcing: 2008 Third-Party Logistics Study: Capgemini Consulting. Available online from: https://www.scl.gatech.edu/research/supply-chain/20083PLReport.pdf. [Accessed 09 September 2014].

Langley, J. Jr. and Capgemini US LLC (2013) 2013 Third-Party Logistics Study: The State of Logistics Outsourcing. Capgemini Consulting. Available online from: http://www.capgemini.com/resources/2013-thirdparty-logistics-study. [Accessed 09 September 2014].

Lee K.H., Kim J.W. (2011) Integrating suppliers into green product innovation development: an empirical case study in the semiconductor industry. Business Strategy and the Environment, 20: 527-538

Levinson, M. (2006) The box: how the shipping container made the world smaller and the world economy bigger. Princeton, New Jersey: Princeton University Press.

Lyridis, D.V., Zacharioudakis, P. (2012) Liquid Bulk Shipping. In W.K. Talley (ed) The Blackwell Companion to Maritime Economics. Oxford: Wiley Blackwell.

Mathers, J. (2012) Smart Moves. Environmental Defense Fund, New York. Available online from: http://business.edf.org/sites/business.edf.org/files/smartmoves_07_screen.pdf [Accessed 110 September 2014].

Memedović, O., Ojala, L., Rodrigue, J-P., Naula, T. (2008) Fuelling the global value chains: what role for logistics capabilities. International Journal of Technological Learning, Innovation and Development 1(3) 353-374.

Mitchell, J., Coles, C. (eds) (2011) Markets and rural poverty: upgrading in global value chains. London: Earthscan, Ottawa: IDRC.

Molnar, J.L., Gamboa, R.L., Revenga, C., Spalding, M.D. (2008) Assessing the global threat of invasive species to marine biodiversity. Frontiers in Ecology and the Environment, 6:485492. doi:10.1890/070064.

Mukherjee, P.K. and Brownrigg, M. (2013) Farthing on International Shipping, $4^{\text {th }}$ Edition. Berlin: Springer-Verlag.

Nadvi, K. (2008) Global standards, global governance and the organization of global value chains. Journal of Economic Geography, 8:323-343.

Notteboom, M.T. (2012) Container Shipping. In W.K. Talley (ed) The Blackwell Companion to Maritime Economics. Oxford: Wiley Blackwell. 
Pike, K., Butt, N., Johnson, D., Walmsley, S. (2011) Global Sustainable Shipping Initiatives: Audit and Overview 2011. A Report for WWF. Available online from: http://awsassets.panda.org/downloads/sustainable_shipping_initiatives_report_1.pdf. [Accessed 10 September 2014].

Ponte, S., Ewert, J. (2009) Which way is 'up' in upgrading? Trajectories of change in the value chain for South African wine. World Development, 37:1637-1650.

Ponte, S., Gibbon, P. (2005) Quality standards, conventions and the governance of global value chains. Economy and Society, 34:1-31.

Ponte, S., Kelling, I., Jespersen, K., Kruiijssen, F. (2014) The blue revolution in Asia: upgrading and governance in aquaculture value chains. World Development, 64:52-64.

Ponte, S., Sturgeon, T. (2014). Explaining governance in global value chains: A modular theory-building effort. Review of International Political Economy, 21(1):195-223.

Poulsen, R.T., Johnson, H. (2015). "The logic of business vs. the logic of energy management practice: understanding the choices and effects of energy consumption monitoring systems in shipping companies", Journal of Cleaner Production, doi: 10.1016/j.jclepro.2015.08.032

Pruzan-Jorgensen, P. M., Farrag, A. (2010) Sustainability Trends in the Container Shipping Industry, Business for Social Responsibility (BSR), September 2010. Available online from: https://www.bsr.org/reports/BSR_Sustainability_Trends_Container_Shipping_Industry.pdf. [Accessed 09 September 2014].

Psaraftis, H. N., 2012, 'Market-Based Measures for Greenhouse Gas Emissions from Ships: A Review Source', WMU Journal of Maritime Affairs, 11(2), 211-232

Rossi, A. (2013). Does economic upgrading lead to social upgrading in global production networks? Evidence from Morocco. World Development, 46:223-233.

Schmitz, H. (2006) Learning and earning in global garment and footwear chains. European Journal of Development Research, 18:546-571.

Scherer, A. G., and Palazzo, G. (2010) The new political role of business in a globalized world: A review of a new perspective on CSR and its implications for the firm, governance, and democracy. Journal of Management Studies, 48(4):899-931.

Skjoett-Larsen, T., (2000) Third party logistics-from an interorganizational point of view. International Journal of Physical Distribution \& Logistics Management, 30:112-127.

Stopford, M. (2009) Maritime Economics, $3^{\text {rd }}$ edition. London: Routledge.

Sturgeon, T.J., Memedović, O. (2011) Mapping global value chains: intermediate goods trade and structural change in the world. Vienna: United Nations Industrial Development Organization.

Tokatli, N. (2007) Asymmetrical power relations and upgrading among suppliers of global clothing brands: Hugo Boss in Turkey. Journal of Economic Geography, 7 (1):67-92. 
Tokatli, N., Wrigley, N., Kizilgün, Ö. (2008) Shifting global supply networks and fast fashion: made in Turkey for Marks \& Spencer. Global Networks, 8(3):261-280.

Trident Alliance, 2014. 'Working together for the enforcement of sulphur regulation', http://www.tridentalliance.org [Accessed on November 11, 2014]

Tzannatos, E. (2010) Ship emissions and their externalities for the port of Piraeus-Greece. Atmospheric Environment, 44:400-407.

van Aardenne, J., Colette, A., Degraeuwe, B., Hammingh, P., de Vlieger, I. (2013) The impact of international shipping on European air quality and climate forcing. Copenhagen: European Environment Agency.

Vurro, C., Russo, A., Perrini, F. (2010) Shaping Sustainable Value Chains: Network Determinants of Supply Chain Governance Models. Journal of Business Ethics, 90: 607621.

Wahl, A., Bull, G.Q. (2014) Mapping Research Topics and Theories in Private Regulation for Sustainability in Global Value Chains. Journal of Business Ethics, 124:585-608

Yeung, H.W., Coe, N.M. (2014) Toward a dynamic theory of global production networks. Economic Geography, doi: 10.1111/ecge.12063.

\section{Notes}

\footnotetext{
${ }^{1}$ When referring to our interviews, we indicate date/month/year of our interviews, as well as positions of interviewees and type of shipping.

${ }^{2}$ Other environmental issues, such as 'particulate matter' and 'black carbon' emissions, underwater noise from propellers and engines and navigation in sensitive areas in the Arctic, are also being discussed in the IMO. At the time of writing, however, these issues remain largely unresolved.

${ }^{3}$ Interview 06/05/13/Executive/Dry bulk shipping.

${ }^{4}$ Interviews 21/05/14/Middle manager/Container shipping; 27/05/14/Middle manager/Container shipping; 03/06/2014/NGO.

${ }^{5}$ Interviews 21/05/14/Middle manager/Container shipping; 27/05/14/Middle manager/Container shipping; 19/06/13/Executive/Dry bulk shipping; 03/05/13/Executive/Tanker shipping.

${ }^{6}$ Interviews 21/05/14/Middle manager/Container shipping; 27/05/14/Middle manager/Container shipping; 17/06/13/Executive/Container shipping; 07/11/12/Middle manager/Container shipping; 07/11/12/Middle manager/Container shipping; 19/06/13/Executive/Dry bulk shipping; 07/05/13/Executive/Dry bulk shipping.

${ }^{7}$ Interview17/04/13/Middel manager/Dry bulk shipping.

${ }^{8}$ Interview 17/04/13/Middel manager/Dry bulk shipping.

${ }^{9}$ Interview 06/05/13/Executive/Dry bulk shipping.

${ }^{10}$ Interviews 29/11/12/Executive/Dry bulk shipping; 15/04/13/Executive/Dry bulk shipping; 17/04/13/Middle manager/Dry bulk shipping, 06/05/13/Executive/Dry bulk shipping;
} 
07/05/13/Executive/Dry bulk shipping; 08/05/13/Middle manager/Dry bulk shipping; 08/05/13/Executive/Dry bulk shipping.

${ }^{11}$ Interviews 03/05/13/Executive/Tanker shipping; 19/06/13/Executive/Dry bulk shipping+Tanker shipping.

${ }^{12}$ Interview 29/11/12/Executive/Dry bulk shipping.

${ }^{13}$ Interviews 26/05/12/Middle manager/Tanker shipping; 26/05/12/Executive/Tanker shipping; 17/08/12/Middle manager/Tanker shipping;17/08/12/Middle manager/Tanker shipping; 24/08/12/Executive/Tanker shipping; 03/05/13/Executive/Tanker shipping; 16/05/13/Executive/Tanker shipping; 16/05/13/Executive/Tanker shipping; 21/05/13/Executive/Tanker shipping; 29/05/13/Middle manager/Tanker shipping; 19/06/13/Executive/Dry bulk shipping+Tanker shipping; 24/06/13/Executive/Tanker shipping; 28/05/14/Middle manager/Tanker shipping; 04/07/14/Middle manager/Tanker shipping.

${ }^{14}$ Interviews 26/05/12/Middle manager/Tanker shipping; 26/05/12/Executive/Tanker shipping; 17/08/12/Middle manager/Tanker shipping; 17/08/12/Middle manager/Tanker shipping; 24/08/12/Executive/Tanker shipping; 03/05/13/Executive/Tanker shipping; 16/05/13/Executive/Tanker shipping; 16/05/13/Executive/Tanker shipping; 21/05/13/Executive/Tanker shipping; 29/05/13/Middle manager/Tanker shipping; 19/06/13/Executive/Dry bulk shipping+Tanker shipping; 24/06/13/Executive/Tanker shipping; 28/05/14/Middle manager/Tanker shipping; 04/07/14/Middle manager/Tanker shipping.

${ }^{15}$ Interview 16/05/13/Executive/Tanker shipping.

${ }^{16}$ We have not been able to assess the level of concentration among container cargo-owners, because both they and shipping companies appear to be secretive on the volumes shipped. A list of the top 10 container importers into the US is available in The Journal of Commerce, May 27, 2013, 14(11) and a list of the largest freight forwarders is available online at: http://www.3plogistics.com/Top_25_Global_FF.htm. These lists give a hint about the scale of the largest container cargo-owners worldwide.

${ }^{17}$ For example, Walmart, the largest company in the world and the largest container importer to the US (JOC, 2012), relies on efficient low-cost shipment of goods along their global supply chains to maintain business competitiveness.

${ }^{18}$ Interviews 21/05/14/Middle manager/Container shipping; 27/05/14/Middle manager/Container shipping; 17/06/13/Executive/Container shipping; 03/06/14/Middle manager/CO; 03/06/14/Middle manager/CO; 16/06/14/Middle manager/CO.

${ }^{19}$ Interview 03/06/2014/NGO

${ }^{20}$ In 2011, the GHG Protocol released a Scope 3 standard (all other indirect emissions beyond Scope 2) to go along with Scope 1 (direct emissions) and Scope 2 (indirect emissions from purchase of electricity). Scope 3 includes 15 categories with two of these pertaining 'upstream transportation and distribution', and 'downstream transportation and distribution'. So far, only 24 of the Global 800 largest companies (across all sectors) report on upstream and none report on downstream transportation emissions (EIO, 2013:15). The leading brand companies that are reporting on the 12 categories within the Scope 3 GHG standard are currently: L'Oreal (4 categories), Sony (3 categories) and Samsung (3 categories) (EIO, 2013). 
${ }^{21}$ Interview 21/05/14/Middle manager/Container shipping.

${ }^{22}$ Interview 16/06/14/Middle manager/CO.

${ }^{23}$ Interviews 03/06/14/Middle manager/CO; 03/06/14/Middle manager/CO; 16/06/14/Middle manager/CO.

${ }^{24}$ Interview 21/05/14/Middle manager/Container shipping.

${ }^{25}$ Interview 02/06/14/NGO.

${ }^{26}$ Interview 28/05/2014/Middle manager/Tanker shipping.

${ }^{27}$ Interview 04/07/2014/Executive/Container shipping.

${ }^{28}$ Interview 04/07/2014/Executive/Container shipping.

${ }^{29}$ Interview 16/06/14/MM/CO. Also supported by several other interviews:

/11/12/Executive/Dry bulk shipping; 15/04/13/Executive/Dry bulk shipping;

17/04/13/MM/Dry bulk shipping; 06/05/13/Executive/Dry bulk shipping;

07/05/13/Executive/Dry bulk shipping; 24/08/12/Executive/Tanker shipping;

26/05/12/MM/Tanker shipping; 26/05/12/Executive/Tanker shipping; 17/08/12/MM/Tanker shipping. 